804

glucagon-like activity (after Shinko's method) of blood were examined with simultaneous foollow-ups of arterial and venous blood sugar levels.

The drug was injected intravenously in the carotid or portal vein. In one type of experiment, the injection was made into the arteria pancreaticoduodenale.

In the latter case, endocrine activity of pancreas was determined with blood drawn from the vena pancreaticus.

The results are summarized as follows :

1) In vitro experiments with the diaphragm, a marked inhibition of glycogenolysis and output of glucose were observed in the incubation medium, containing $10 \mu \mathrm{g} / \mathrm{ml}$ D860. With Krebs-Ringerglucose medium glucose uptake and glycogen synthesis showed a 30 per cent increase.

2) With the liver slices, a similar phenomenon was observed within 10 to $100 \mu \mathrm{g} / \mathrm{ml}$ concentration of sulfonylurea. D860 was most effective and IBTD with concentration of 10 to $100 \mu \mathrm{gml}$ also showed strong inhibition of glycogenolysis. With Buchanan-Hastings-Nesbett solution, the author observed acceleration of glucose uptake and glucogensynthesis with sulfonyl-urea concentration of $10 \mu \mathrm{g} / \mathrm{ml}$.

3) Sulfonylurea in concentration over $300 \mu \mathrm{g} / \mathrm{dl}$ caused increased glycogenolysis and glucose output of the diaphragm and liver slices, particularly of the latter.

4) Experiments with the liver slices under glycogenetic conditions, i.e. Buchanan-Hastings-Nesbett solution with $1000 \mathrm{mg} / \mathrm{dl}$ glucose showed no apparent change in glycogen synthesis but in the environment without glucose D860 showed inhibition of glycogenolysis, thus indicating the glycostatic effect.

5) Investigation of insulin-like activity and glucagon-like activity of blood drawn from the vena pancreaticus revealed a pattern of response upon injection of D860, which was quite similar to that observed following glucose injection, i.e. there was an increase of insulin-like activity 2-3 hours after injection of glucose or D860.

6) From the investigations above mentioned the author reached the conclusion, that sulfonyl-urea exerts it's first phase effect through the accelerated consumption of endogenous insulin thus inviting initial hypoglycemia and initial decrease of insulin-like activity of plasma. The second phase effect observed, was the increase of insulin secretion, inhibition of glucose output from liver, increase of glucose uptake in the peripheral tissues and consequent retardation of restoration of hypoglycemic blood sugar level.

7) The present day concepts upon the mechanism of antidiabetic sulfonylurea was discussed from the results of our own experiments and references.

\title{
Studies on the Physiologic Role of Glucagon with Special Reference to the Cooperation of Glucagon and Insulin in the Control of Carbohydrate Metabolism
}

\section{Toshihiko HASHIMOTO}

\author{
Department of Internal Medicine, Division II, Kobe Medical College, Kobe
}

(Directer : Professor S. Tsuji, M.D.)

The role of glucagon in carbohydrate metabolism seems to be better understood nowadays.

But since there is no reliable bioassay method for the estimation of glucagon-like activity (Abbr.

Vol. 37 No. 8 
as glucagon activity) in blood, no detailed studies on the role of glucagon in the carbohydrate metabolism could be carried out.

In our clinic, a new bioassay method of blood glucagon activity was developed by Shinko, basing the glucagon activity on the liver slices.

By using this method, the author tried to analyse the physiologic role of blood glucagon.

The results are summarized as follows :

(A) Studies with in vitro technique.

Wistar strain rats were used, weighing 100 120gm. They were fed for 3 to 5 days with a carbohydrate rich diet and then made to fast for 48 hours. This experimental condition was necessary to standardize the glycogen content of the rat liver. Liver slices were taken and then incubated in Warburg's apparatus. As incubation medium, modified Buchanan-Hasting's Solution with 1000mg./dl. glucose, was used. Novo-semilente insulin or Glucagon-Lilly was added to the medium in various concentrations. $\Delta$-glucose in the medium and $\Delta$-glycogen of the liver were examined and these values were observed.

The values are summarized as follows;

(1) Increasing doses of insulin added to incubation medium usually increase $\Delta$-glycogen and glucose uptake

(2) When glucagon was added to the Insulin free (incubation) medium, in which liver slices were incubated, no particular change of glucose uptake was observed with low concentration of glucagon. If the doses of glucagon is elevated to $1 \mu \mathrm{g} . / \mathrm{ml}$. or more it causes only a slight decrease of glucose uptake and 4 -glycogen.

(3) When insulin was added to the medium, which contained $10^{-4} \mu \mathrm{g} . / \mathrm{ml}$. of glucagon, glucose uptake from the medium increased but this increase of glucose uptake was lower than that in the experiment, in which no glucagon was added to the medium. 4 -glycogen of the liver slices decreases under insulin addition. These results indicate the possible co-action of glucagon and insulin in some instances.

(4) When insulin was added to an incubation medium, of which glucagon concentration was $10^{-2} \mu \mathrm{g} . / \mathrm{ml}$, there was an increase of glucose uptake under insulin action. On the other hand, action of glucagon is potentiated by insulin and this leads to increased glycogenolysis. These two reactions act antagonistically to each other, the result of which is expressed as a mild fluctuation of glucose uptake.

(5) When insulin is added to a medium, which contains glucagon to $1 \mu \mathrm{g} / . \mathrm{ml}$. or $10 \mu \mathrm{g} . / \mathrm{ml}$. concentration, a progressive glycogenolytic action of glucagon is observed with the addition of increasing doses of insulin.

(6) Glycogenolytic effect of added glucagon on the liver glycogen was detectable for about 30 minutes in case of simple glucagon action. In 120 minutes, glycogenolitic effect of added glucagon is over and there is an enhanced glucose uptake from the medium as compared with liver slices incubated in simple Buchanan-glucose medium.

Thus glucagon effect is suppressed by coexisting insulin in the first phase of time, but on the whole, this glucagon effect has a tendency to remain active for a long time.

Glycogenolytic effect of epinephrine and glucagon on the liver slices was compared in a medium, to which $1 \mathrm{u} . / \mathrm{ml}$. insulin was added. In the first phase of epinephrine action, slight glycogenolysis was seen but in the course of 120 minutes, the glycogenolytic effect of epinephrine was over and even the glucose uptake from the medium was observed. In the same kind of experiment where glucagon was used instead of epinephrine, there was an enhancement of glycogenolysis. These results point

Vol. 37 No. 8 
to quite a different mode of action of glucagon and epinephrine.

(B) Experiments in vivo :

Dogs weighing 6-10kg were used. A small vinyl tube was inserted into the portal vein and various hormones were injected through this route. Two hundred $\mathrm{mg}$. of liver slicces were successively resected after liver glycogen estimation. Blood was drawn from V. pancreatico duodenalis, jugular vein and femoral artery and vein. Blood glucose value was examined with blood samples taken from the femoral artery and vein, and A-V ratio was calculated. Blood was drawn from the cubital vein of normal subjects and diabetics in the post absorptive condition.

Insulin like activity of plasma was estimated after Shimazu's rat diaphragm method and serum glucagon activity after Shinko's method. The results of experiments are summarized as follows :

(1) Simultaneous injections of insulin and glucagon into the portal vein of dogs brings about mutual enhancement of physiologic effect of both hormones, i.e., one can see the enhanced hyperglycemia and the aggravated hypoglycemia in the last phase of observation. Hyperglycemia as well as hypoglycemia was more prononuced than in the case of simple glucagon or simple insulin effect.

(2) That the main action of glucagon takes place in the liver is a well known concept. The author thus tried to build up a linear ratio between glucagon like activity of blood drawn from cubital vein-glucagon like activity of blood drawn from portal vein, and the glycogenolytic effect of glucagon on the liver glycogen. But in fact no such relations could be verified.

(3) Simultaneous observations of glucagon like activity and insulin like activity were carried out on normal subjects and on diabetics. From the results obtained a formula could be deduced as follows: Insulin $(\mathrm{u} / \mathrm{ml}):$ glucagon $(\mu \mathrm{g} / \mathrm{ml})=1: 10$

As an another kind of regularity, a see-saw relation was noted on diabetics between glucagon like activity of blood and insulin sensitivity of diabetics. 


\title{
Glucagon に関する実験的研究
}

\author{
神戸医科大学第二内科学教室 (指導 辻 昇三教授) \\ 橋本利彦
}

(昭和36年 1 月 30 日受付)

\section{緒 言 \\ I 実験対象及び実験方法 \\ [1] in vitro の実験 \\ [2] in vivo の実臨 \\ II 実験成績}

[1] in vitro の白鼠肝切片糖代謝に及ほ す添加 Glucagon 及び Insulin の 影響

(I) Insulin 及び Glucagon の各種濃度 比の肝切片糖代謝に及ほすす影響に就 いて

（II）肝切片糖代謝に対する Insulin 及び Glucagon 添加の影響の時間的钼察

(III) 小 括

[2] in vivo に於ける Glucagon acti-

\section{内 容 目 次}

vities 亿対する Insulin 作用の相関

（I） 犬血糖及び肝糖原に及ぼす Glucagon 負荷時の影響に就いて

（II）正常犬肝糖原量之膵静脈内 Glucagon like activity の関係に就いて

（III）正常人及び糖尿病患者血清中 Insulin like activity 及び Glucagon like activity に就いて

（IV）桾尿病患者血清中 Glucagon like activity $\prec$ Insulin sensitivity $\odot$ 関係に就いて

(V) 小 括

III 考 按

結 語

\section{緒言}

Insulin 発罗の翌年に始まる Glucagon 研究の歴史は Bürger一門の根気のよい精細な探究1)の後をうけた

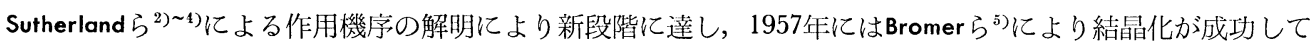
いるので現在では Glucagon が膵藏 Langerhans 氏島 $\alpha$ 細胞より産生されるホルモン様物質である事は一 般に承認されている．本物質の生理的作用及び生物化学的特性に就いてはすでに Sutherland ら ${ }^{2) \sim 4) ， B u ̈ r g e r ~}$

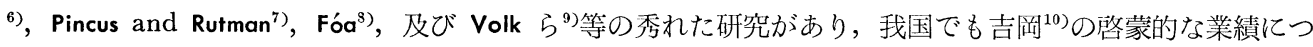

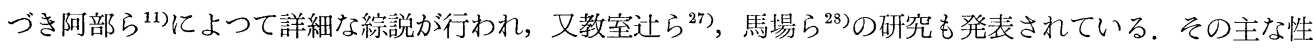
質として，1)微量有効物質であつて，インシュリンと同様にアミノ酸組成が決定され，2)主として膵ラ氏島 から産生され，3)血中有効物質としての存在が証明され，4)恐らく脳下垂体の生長促進ホルモンを上位ホル モンとして調節されておるかに見え，4)有効な生理作用としては Phosphorylase 活性の充進を通じて肝糖 原を分解し，高血糖を来すが筋肉糖原には作用しない点でアドレナリンと異る，等主として糖代謝に関する 作用がほぼ確認されているが，尚問題が残されている，殊に使用しやすく且つ信頼のおける血中 Glucagon 活性値の微量定量法がないため，その分泌機転，生理的及び病態生理的意義に就いては未開拓の分野が多く 残されている現状である.

著者は辻，馬場 ${ }^{12}$ に始まる一連の in vitro の糖代謝研究に参加し，肝糖原に対する Glucagon の作用殊 に Insulin との相互作用に就いて検討し，又その中で新光 ${ }^{13}$ の考案した方法を用いて血中 Glucagon 活性 值の測定を行い若干の知見を得る事が出来たので以下に報告したい. 


\section{I 実験対象及び実験方法}

\section{[1] in vitro の実験}

第 1 表 Conditions of Rats and Liver Glycogen Content.

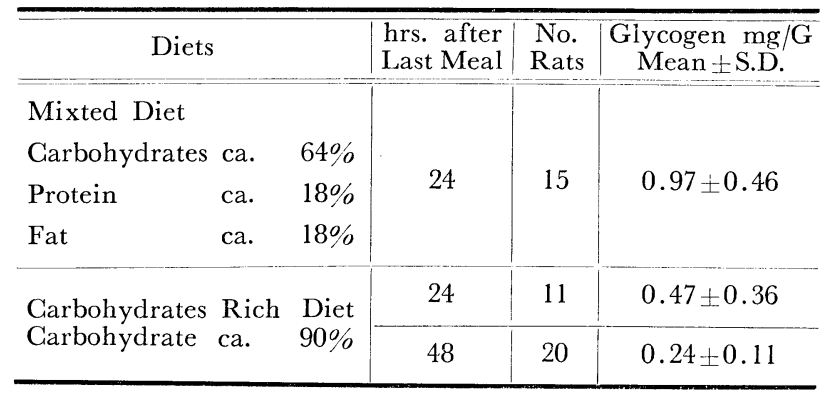

辻, 馬場 ${ }^{12)}$ の方法に従つて Warburg 装置を用心，動物は Wistar 系 白鼠を使用した。初期の実験では混 合食を与え，24時間絶食後使用した が肝糖原量に相当の変動があり, 又 in vitro での反応度も一様でないと の印象をうけたので第 1 表の如く実 踰前 $3 \sim 5$ 日間高含水炭素食を与光， 48時間絶食させる事に依り略々均一 な状態を得る事が出来た。

白鼠は絶食後頭部打撲, 頸動脈を切断, 放血致死せしめ迅速に肝茈を摘出し, free hand で厚さ約 $0.3 \mathrm{~mm}$ 重量約 $100 \mathrm{mg} の$ 切片としフラスコに投入 incubate した。実験は必ず同一肝践より作製した切片のうちから 対照をとつて行つた.

Incubation medium : modified Buchanan-Hastings' solution を使用, 葡萄糖添加は $1 \mathrm{~g}$ per dl とした (BGと略記する). Insulin はNovo-semilente Insulin を, Glucagon は Glucagon-Lilly を使用した。な お記载を籣便にするため，I $(0.1)$ 又は $\mathrm{G}\left(10^{-3}\right)$ として夫々 Insulin $0.1 \mathrm{U} / \mathrm{ml}$, Glucagon $10^{-3} \mu \mathrm{g} / \mathrm{ml}$ を表す 事とし，BGI $(0.5) \mathrm{G}\left(10^{-3}\right)$ と略記して Insulin $0.5 \mathrm{U} / \mathrm{m}$, Glucagon $10^{-3} \mu \mathrm{g} / \mathrm{ml}$ を含む BG medium を示す 事とする.

Incubating condition : Warburg 装賀を用い，気相は $\mathrm{CO}_{2} 5 \%, \mathrm{O}_{2} 95 \%, 37.5^{\circ} \mathrm{C}$ 於いて 1 分間90回振動, 90分間 incubate し medium 中の葡䓒糖量, 組織糖原量を測定し実験前值との差を各々糖利用, 糖原合成 とした.

測定法：莆萄糖定量は Hagedorn-Jensen 法 ${ }^{14)}$, 糖原は Good, Kramer \& Somogyi 法 $^{15}$ 変法によつた。

\section{[2] in vivo の実験}

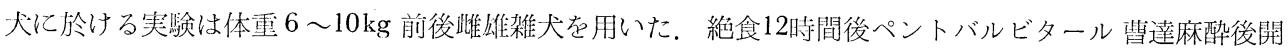
腹し，まず腸間膜静脈より細いビニール管を門脈に向つて插入し薬䍏の注入を行える様にし，ついで小尖刀 をもつて肝缄より $200 \mathrm{mg}$ 前後の小切片を得て肝糖原測定用とし以下継将的に採取してその動態を追求した。 採血は目的により Vena pancreatico-duodenalis, V. jugularis 及び A.V. femoralis より採血し, A-V ratio は同洔採血した股動静脈血糖产と股動脈血糖值の比をもつてあらわした。

正常人及び糖尿病者についての測定は早朝空腹時肘静脈血について行つた.

Insulin 相当值は島津 ${ }^{24}$ の方法により, Glucagon 相当值は新光 ${ }^{13)} の$ 方法によつた.

\section{II 実 験 成 績}

\section{[1] in vitro の白鼠肝切片糖代謝に及ぼす添加 Glucagon 及び Insulin の影響}

（）Insulin 及び Glucagon の各種濃度比の肝切片糖代謝に及ぼす影響に就いて：まずInsulinの影響を 確認するため $\mathrm{BG}$ medium に0.05U/mlより $1 \mathrm{U} / \mathrm{ml}$ 迄 4 段階の Insulin 添加を行うと (第 2 表), Insulin の增量とともに Glucose-uptake は次第に増加し BGI (1.0)では無添加対照の2.2倍迄増加し, 一方 4 -glycogen も㴬増するが増加率は Glucose-uptake に比して低く, BGI(1.0)でも約 $33 \%$ の増加にすぎない事が

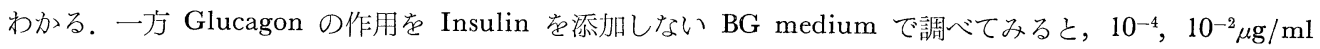
の少量では殆んど無添加対照と変化なく，1 $1 \mathrm{~g} / \mathrm{ml} ， 10 \mu \mathrm{g} / \mathrm{ml}$ に於いて僅に Glucose-uptake 及び $\Delta-G l y-$ cogen 減少を認めるにすぎず Glucagon の所謂 Glycogenolytic effect が充分あらわれているとは云えない. 
第 2 表 白鼠肝切片糖代謝に対する Glucagon 及び Insulin 添加の影響

(Modified Buchanan solution with $\mathrm{lg} / \mathrm{dl}$ glucose)

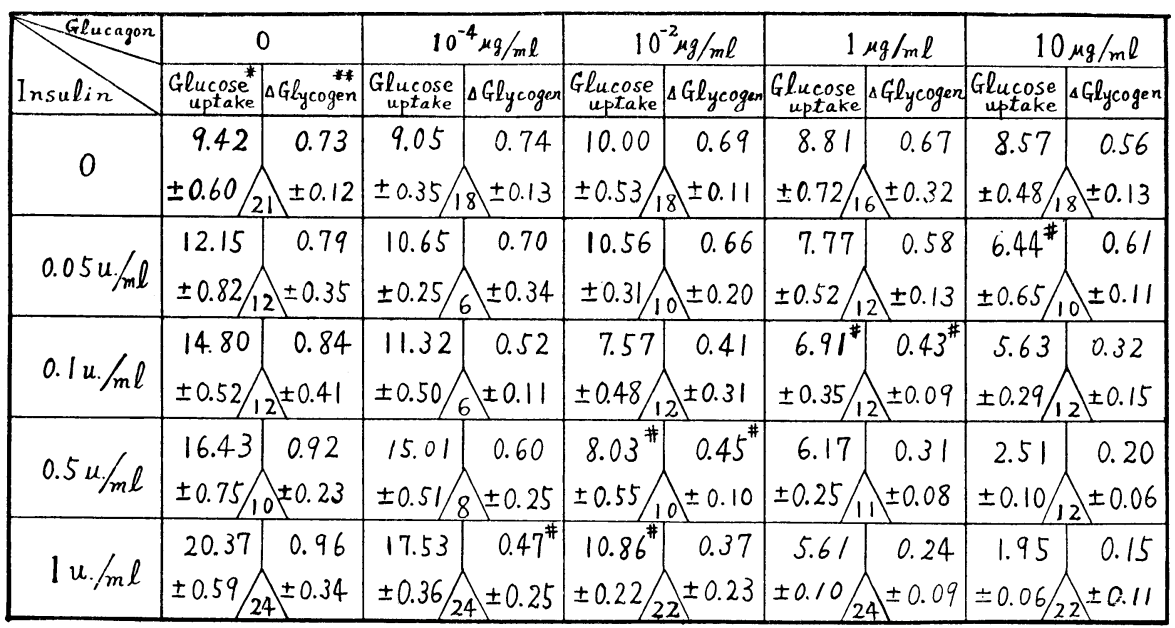

$\triangle$ 内は例数，Dataはすべて Mean士S.E.

* Glucose uptake : $\mathrm{mg} / \mathrm{Gm}$. wet tissue weight / $90 \mathrm{~min}$.

** ^Glycogen : $\mathrm{mg} / \mathrm{Gm}$. wet tissue weight $/ 90 \mathrm{~min}$.

しかし乍ら第 2 表最下列に示す様にBGI (1.0)に対して Glucagon を階段的に添加すると, 明白に Glucoseuptake と $\Delta$ Glycogen の減少があり, BGI $(1.0) \mathrm{G}(10)$ では Glucose-uptake は BGI $(1.0)$ の1/10以下の低值 で G Glycogen は同しくくその1/6.4となり，BGI $(1.0) \mathrm{G}\left(10^{-4}\right)$ そ至る迄 Glucagon 濃度に略々比例した Glucose-uptake, AGlycogen の減少を認める. 即ち Insulin の存在が BG medium に於ける添加 Glucagon の作用発現に重要な因子である事か卯象づけられ，更に Glucagon の各濃度に就いて詳細に Insulin 濃度 との関係を検討してみるとての印象を裏附ける興味ある相関関係があきらかとなつて来る。

まず BGG $\left(10^{-4}\right)$ の系列に就いてみると, Insulin 無添加では Glucagon effect の認められないものが BGI (0.05) G $\left(10^{-4}\right)$ ですでに Glucose uptake の増加率は少く， $\Delta$ Glycogen は僅か乍ら減少し明かに $10^{-4} \mu \mathrm{g}$ $/ \mathrm{ml}$ に於ける Glucagon effect を示し，乙の傾向は添加 Insulin 濃度の増大とともに明白となる.

即ち Insulin による Glucose-uptake 及び cogenolytic effect の増大とが逆方向に作用し合うものと考えられ，BGG $\left(10^{-2}\right)$ ではこの両作用が略々等し い力を示すものの如くで BGI $(1.0) \mathrm{G}\left(10^{-2}\right)$ では Glucose-uptake は BGG $\left(10^{-2}\right)$ と近似し, BGI $(0.5) \mathrm{G}\left(10^{-2}\right)$ 及び BGI (0.1) G $\left(10^{-2}\right)$ では Insulin effect よりも Glucagon effect がやや強く Glucose uptake は減少を 示している. 但し $\Delta$ Glycogen に就いては Glucagon effect が常に Insulin effect より大であるものの如 くで Insulin 量増加とともに減少を示す。

$1 \mu \mathrm{g} / \mathrm{ml}$ 以上の Glucagon 濃度では Insulin による Glucose uptake 增加よりもそれによつて活性化さ れる Glucagon effect の方が常に大であつて Insulin 濃度の増加とともに Glucose uptake, AGlycogen減 少を認め殊に $10 \mu \mathrm{g} / \mathrm{ml}$ 亿於て明かである。

以上の事実を観点をかえて眺めてみると， BGI (0.05) の列に於て Glucagon 無添加の場合の Glucose uptake $12.15 \mathrm{mg} / \mathrm{G}$ を半減せしめる添加 Glucagon 量は第 2 表中に BGI $(0.1)$ ではそれが $1 \mu \mathrm{g} / \mathrm{ml}$ の Glucagon 添加によつて認められ 4 Glycogen も同じく $1 / 2$ となつている.

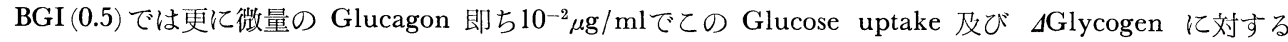
半減効果が得られ，BGI(1.0)では Glucose uptake を半減せしめるにはやはり $10^{-2} \mu \mathrm{g} / \mathrm{ml}$ 要するが $\Delta \mathrm{Gly}$ 
第 1 図肝切片糖代謝に対する Glucagon 及び Insulin 添加の影響(各 4 例)

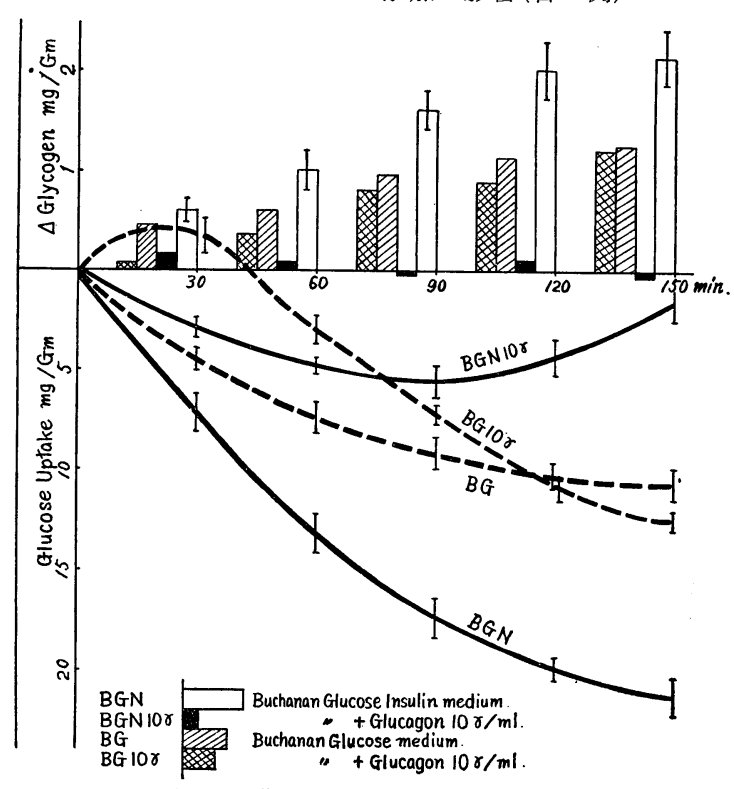

第 2 図 肝切片糖代謝に対する Glucagon 及び Adrenalin (Bosmin) 添加の影響 (各 4 例)

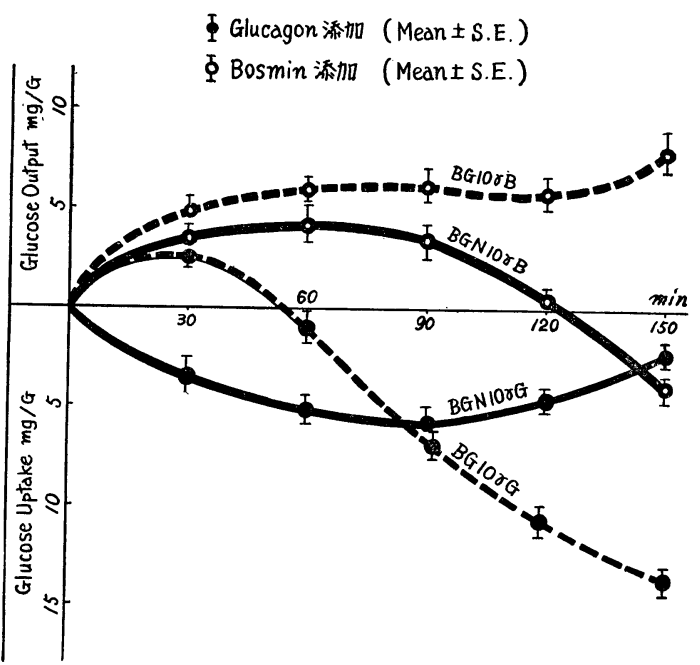

BG10 $\mathrm{G}$ : Buchanan solution $1 \mathrm{~g} / \mathrm{dl}$ glucose $+10 \gamma / \mathrm{ml}$ Glucagon BGN10rG : Buchanan glucose solution $1 \mathrm{U} / \mathrm{ml}$ Insulin $+10 \gamma / \mathrm{ml}$ Glucagon

BG10 B : Buchanan glucose solution $+10 \gamma / \mathrm{ml}$ Bosmin BGN10 $\gamma$ B : Buchanan glucose solution $1 \mathrm{U} / \mathrm{ml}$ Insulin $+10 \gamma / \mathrm{ml}$ Bosmin cogen は $10^{-4} \mu \mathrm{g} / \mathrm{ml} の$ Glucagon 添加によ り無添加対照の $0.96 \mathrm{mg} / \mathrm{G}$ 亿対し $0.47 \mathrm{mg}$ / Gと減少している。

以上の成績は何れも Glucagon 作用が共 存する Insulin 濃度に影響される事を示 し，乙の表に見る範囲では $1 \mu \mathrm{g} / \mathrm{ml}$ 以上の 濃度では Insulin の Glucagon 作用増強 作用の方がそれ自身の機能より強くあらわ れ， $10^{-2} \mu \mathrm{g} / \mathrm{ml}$ 濃度ではほぼ平衡， $10^{-4} \mu \mathrm{g} /$ mlでは Glucose uptake に対しては Insulin 効果が認められている。

（II）肝切片糖代謝に対する Insulin 及 び Glucagon 添加の影響の時間的観察 : 前 項に述べた Insulin による Glucagon 作 用の増強が如何なる機作によるかを解明す る為，先ず BG及び BGI(1.0) medium 及 びてれに $10 \mu \mathrm{g} / \mathrm{ml}$ の Glucagon を添加した ものをもつて白鼠肝切片を incubate し， 継時的にその Glucose uptake と $\Delta \mathrm{Gly}$ cogen に対する影響をみてみると, BG, BG I(1.0) medium とも150分に至る迄糖利用, 糖原合成とも増加し, 当然ではあるがInsulin 添加 medium に於て著明である。乙 の条件に Glucagon $10 \mu \mathrm{g} / \mathrm{ml}$ を附加してみ ると BG medium と BGI (1.0) medium に於てその影響に著しい特色を見出す事が 出来る. 即ち BG medium に Glucagon $10 \mu \mathrm{g} / \mathrm{ml}$ を添加すると(第 1 図, BG $10 \gamma$ で 示す破線）30分後には一過性の糖放出をみ るが60分後には uptake に転じ，以後はむ しろ BG mediumよりも急激に増加し150 分では BG 值を上廻る糖利用をみる事が出 来る. BGI (1.0)ではこれとは異り, 同量の $10 \mu \mathrm{g} / \mathrm{ml}$ Glucagon 添加にも関らず30分で みられる Glucose output はなく90分迄軽 度に増加する Glucose uptake がみられる のみである. 即ち BG medium では Glucagon は急速に肝切片に作用して糖放出を 行わしめ肝糖原減少を惹起させるが， BGI (1.0) では添加 Glucagon は緩除にその作 用をあらわし150分に至る迄 4 Glycogen は 殆んど認められず Glucose uptake もあき らかに抑制されている。乙の結果からみる 
と Insulin 添加の作用は肝と Glucagon の急速な反応を抑制する事により Glucagon の分解をさまたげ， 長時間作用せしめる点にある様に見える。

この Insulin による Glucagon の分解抑制はての両ホルモン相互間の特殊な親和性によるであろう事は 両者のア之ノ酸組成の近似からも類推される所であるが，同様な解糖作用を持つ Adrenalin と比較してみ ると第 2 図の如く Adrenalin では BGI(1.0) medium に於て逆に Glucose output が少くしかもその作用 は120分以後は消失し, Glucose uptake が認められるので Insulin 共存の場合に反つて添加ボスミンの分解 が促進されるが如き結果となつている。従つて Insulin による glycogenolytic effect の増大は Glucagon に特異なものであると云える.

（III）小括：in vitroに於ける白鼠肝切片糖代謝に及ぼす Glucagon の影響に就いてはすでに辻，馬場 ${ }^{12)}$ による報告があり, 前述した如く白鼠飼育絶食等の処置が異つているためと使用した Insulin に Glucagon が混在していたため充分な成績を得る事が出来なかつたが，glycogenolytic effect が Insulin により增強 される事を指摘し，又濃度によつて協調作用のある事を述へている．Glucagon の解糖作用が Insulin 亿依 り増強される事は本実験によつて充分立証されたものと考学られ，又前述の如く糖利用及び糖原合成を半減 せしめるに要する Glucagon 量が共存 Insulin 濃度の增大とともに減少する事実は濃度による協調関係を 端的に示すものであろう.

なお本実験では触れなかつたが白鼠横隔膜て就いて辻，馬場 ${ }^{22)}$ は糖原合成条件で Insulin 亿似た作用を見 出し, 又 Insulin との相関について Insulin 濃度の上昇と共に筋に於て糖原合成の抑制がみられる事あり と報告し，乙の場合も Insulin, Glucagon 両者共混在物をもつている可能性を指摘している. 白鼠摘出横 隔膜糖利用汇関する Glucagon の態度に就いては Candela ${ }^{16)}$, Candela \& Candela ${ }^{17)}$ 及び Snedecor ${ }^{18)} ら$ Insulin effect を抑制するとするもの又阿部ら ${ }^{199}$ の如く促進すると主張するものあり, 又 Glucagon 自体に 就いても促進作用はないと云う阿部ら ${ }^{20}$ の成績と自体にあるとする $\mathrm{Smith}^{21)}$ の意見が対立していたが，Ran$\mathrm{dl}^{22223)}$ は一連の周到な実験によつて Glucagon 中に Insulin activity の混在する事を証明しているので辻， 馬場 ${ }^{12)}$ の実験成績の解勫は妥当であつたと思われる.

肝切片に於て Insulin の存在のもとで Glucagon effect が大である事は Tyber-

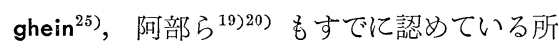
であるが，その機転は de Duve ${ }^{26)}$ の云う様に 単に Glucagon の分解を Insulin が阻止す るためであるか早急に判定を下す事は困難で ある，著者の成績よりみても Insulin 濃度 と Glucagon 濃度の一定の比率が in vivo そ於ける Glucagon effect を決定するとの 印象が強く, なお慎重な検討を要するものと 考えている. 従つて以下 in vivo の実験もと の方向の探究を目的として進めた.

〔2〕 in vivoに於ける Glucagon activities に対する Insulin 作用の相関

（Ｉ） 犬血糖及び肝糖原に及ぼす Glucagon 負荷時の影響に就いて：前述の方法によ り正常大を処置し血糖及び肝糖原前值を測定 してのち門脈に擤入したビニール管を通じ Insulin, Glucagon 又は両者の混合液を注入 し肝糖原変動, $\mathrm{A}-\mathrm{V}$ ratio, 及び血糖（股静
第3 図 Insulin, Glucagon 又は両者混合門脈 内注入時血楉及び肝糖， A-V ratio の 変動（各点 3 回測定）

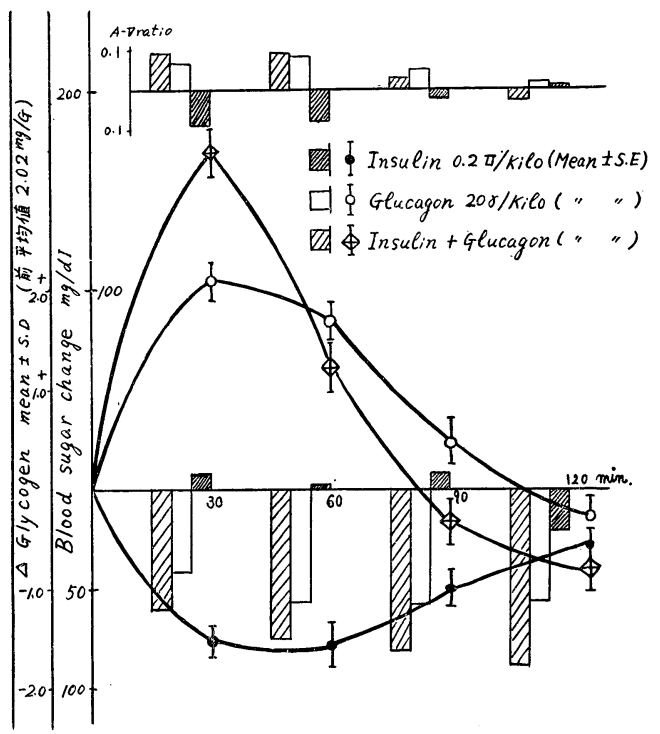


脈)を追求し第 3 図の如き結果を得た。Insulin（Novo regular） $0.2 \mathrm{U} / \mathrm{kilo}$. 注入では30分後すでに著明な 低血糖に陷るが肝糖原は大きな変動を示さず $\mathrm{A}-\mathrm{V}$ ratio は逆転を示し120分後よりやや恢復に向う。一方 Glucagon $20 \gamma /$ kilo を単独注入した場合は著明な高血糖が発来し之を反映して 肝糖原も明らかな減少を示 している．乙の二つの反応は当然予想される所であるが，ての両者を混合し一時に門脈内に注入した場合の 反応は常識的には両者の算術和としてあらわれる可能性が最も大であり, 前述の in vitro の Insulin との 相互作用よりみて持続的な高血糖反応が起る可能性も考えられる。実際に正常犬 3 例に就いて行つた平均は 第 3 図に示す如く著明な高血糖反応と肝糖原分解があり，更に特異な点は高血糖の持続は比較的短時間で注 入後90分ではすでに前血糖值より低下し，120分では過剩反応的な低血糖状態を示す事である。乙の様な血 糖変動に対応して A-V ratio も高值をとり末梢での糖処理が良好である事を示唆しているので, Insulin の 共存は in vivo に於ては単に Glucagon effect を增強すると云う一方的な役割でなく Insulin 作用もま た Glucagon の存在によつて修飾をうけているものと考えられる。

（II） 正常犬肝糖原量亡膵静脈内 Glucagon-like activity の関係に就いて：Glucagon か朋を主たる作用点 とする以上肝臓, 即ち肝糖原量と密接な量的関係を持ち, 殊に膵十二指腸静脈血中値と肝通過後の頸静脈等 末梢血中值との比が肝糖原値によつて変化するであろうとの推定は決して無理ではない． 新光 ${ }^{13)}$ はすでに正 常犬 8 匹平均として膵十二指腸静脈血中 Glucagon-like activity が2.9: 1 の比で股静脈血中值より高い事を 報告しているが，著者の正常大 9 例では平均 $2.46: 1$ の比で膵十二指腸静脈内高值を示している（第 4 図 $\mathrm{a}$ ， $\mathrm{b}$ 参照).

併し乍ら個々の例に就いて検討してみると No. 7 の如く著明な Glucagon-like activity の較差を示す例 飞於て肝糖原高值を示すものもあるが，同様な肝糖原值をとり乍ら No. 8 の如く Glucagon-like activity 亿

第 4 図a グルカゴン相当值と肝糖原

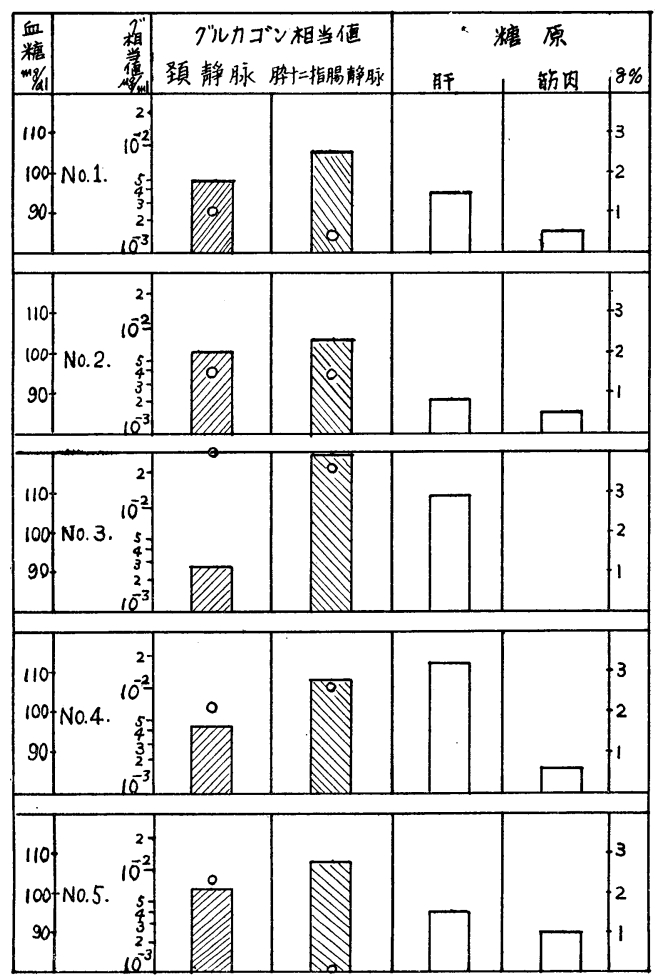

第 4 図 b グルカゴン相当值と肝糖原

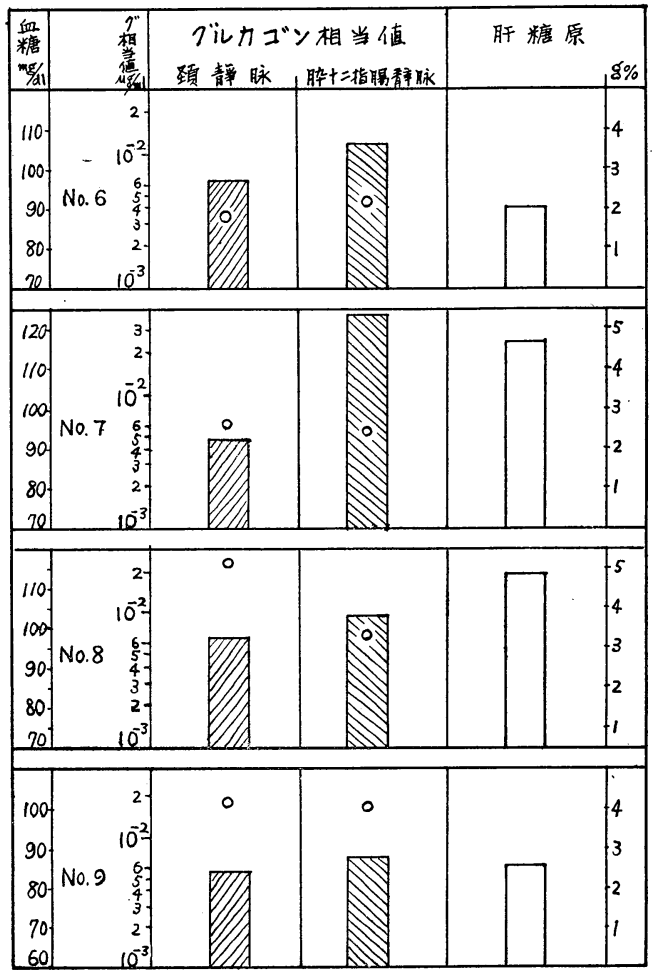


較差の少い例もあつて一定の関係を証明する事が出来なかつた。

従つてての場合も Glucagon の作用は単に肝糖原との直接的な結合ではなく Insulin 其他との動的平衡 によつて膵静脈血中 Glucagon 活性值の昇降, 肝糖原との相互作用量の多蒠が決定されるものと思われ, 例えば in vitro で証明した如くInsulin 活性の低い環境ではたと光肝糖原量が高くとも肝解糖，Glucagon 分解は起らず，むしろ肝糖原は比較的低值でも充分量の Insulin が存在すれば Glucagon effect は強くあ らわれる可能性があるものと考えられる，以上の観点より血清中に於ける Insulin と Glucagon 相当值が 如何なる比をもつて存在するかが一つの興味ある研究課題として提起される.

（III） 正常人及び糖尿病患者血清中 Insulin-like activity 及び Glucagon like activity に就いて：健常人15 例，糖沓病者21例に就て血清中 Insulin 及び Glucagon-like activity を同時に測定し図示すると，第 5 図 の如く正常例及び糖尿病の一部は群をなしほぼ一定の比率が存在する事を想像せしめる. 即ち Insulin-like activity は $10^{-4} \mathrm{U} / \mathrm{ml}$ 近傍にあり, Glucagon-like activity は $10^{-3} \mu \mathrm{g} / \mathrm{ml}$ 附近にあるから単位を別にすれば Insulin と Glucagon は略々 1：10の比をもつ事となる。この比率は in vitro の実験仿て強い協調作用を 示していた比率であつて，勿論絶対值は何れも1000分の1であるが血中值が同一比率を示す事は Insulin 及 び Glucagon 活性が別個のものではなく，密接な相互関係のうちに生理作用を営んでいる一つの証拠と考学 られる。糖尿病症例及び内分泌疾患等による異常比率の意味づけは己に一部辻ら ${ }^{2728)}$ の報告にもあるが別に 詳報する予定でこてには触れないが，図中××で示したアクロメガリ一患者，で示したステロイド糖尿病 者例等重篤な内分泌失調を伴う糖代謝異常が Insulin, Glucagon ratio の異常を伴う点はまことに與味のあ る問題点である.

第 5 図 Serum-Insulin Eq. \& Glucagon Eq.

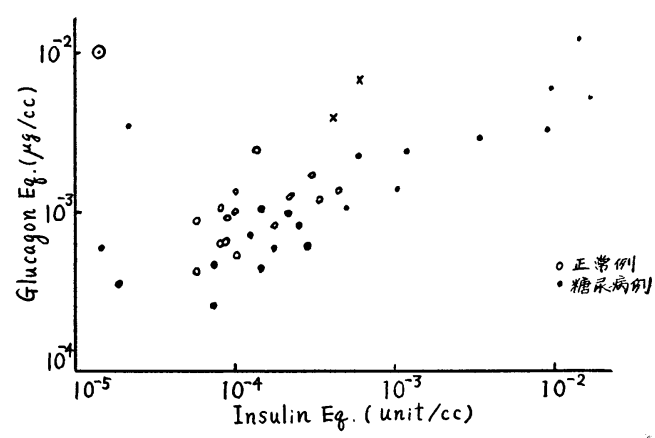

第6 図 Serum-Glucagon Eq. \& Insulin Sensitivity.

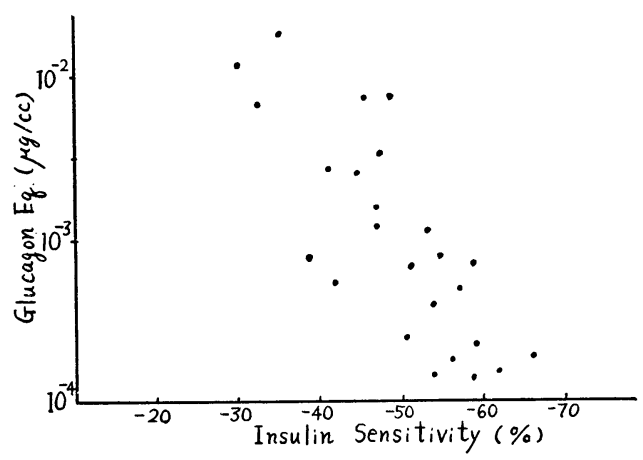

（IV）糖尿病患者血清中 Glucagen like activity ट Insulin Sensitivity の関係に就いて：前項の様な静的な 状態に於ける血清 Glucagon like activity と Insulin-like activity の比較ではなく, 更に動的な平衡関係 を窅う目的で第 6 図に示す如く単純インシュリン10単位皮下注射法に依る血糖下降試験を行い，前血糖值に 対する増减百分率をもつて Insulin sensitivity とすると,ての Insulin sensitivity と血清中 Glucagon like activity との関係は図の如く逆相関を示し，血清中 Glucagon like activity の高いものは Insulin sensitivity が低下している。一般に Insulin sensitivity が低下しているものは所謂多腺性因子の多いものが大部分で 第 5 図に示す通り $10^{-2} \mu \mathrm{g} / \mathrm{ml}$ 程度の高值をとるものにはステロイド糖尿病, アクロメガリー等が含まれ Glucagon activity の高い事もこの面汃了解される。しかし乍らての逆相関は $10^{-3} \mu \mathrm{g} / \mathrm{ml}$ 程度の Glucagon 濃 度に於てもなお明膫に認められるので, 全てを多腺性因子をもつて解勫する事は困難であり, 上記述べ来つた Insulin activity と Glucagon activity の比率の問題がその解答のために考慮されねばならない(第 2 表参 照). 即ちせまい範囲であるが Insulin, Glucagon 1:10の比率の BGI (0.1) G (1.0) 亿於て, Insulin 濃度を 増加せしめ BGI (0.5) G(1.0) とすれば，増加した Insulin の効果は Insulin 自体の糖利用促進効果よりも Glucagon effect の増强剤として作用し, 逆に Glucose uptake の減少, ১Glycogen の減少を惹起している. 
勿論との様な in vitro の成績を直接 in vivo そあてはめる事は無理があり，in vitro の成績自体が Glucagon 濃度の低い所では全く逆に促進をみるのであるから, 未だ一つの仮説にはすぎないが相当な血中 Glucagon activity をも患者に於ける Insulin 負荷はある意味でGlucagon activity の potentiation となる 場合があり，Insulin sensitivity としては減少の傾向を示すものではないかと考光られる。

（V）小括：in vitro 亿於ける Insulin と Glucagon の相互作用の知見任基き，先ず in vivo 亿於て正 常犬門脈内に Insulin, Glucagon 及び両者の混合液を注入する事により, Insulin と Glucagon が相乗作 用を示し血糖上昇度は Glucagon 単独よりも著明であり, 又 Insulin effect も增強され強い低血糖を現出 する事を認めた。この様に Insulin, Glucagon は互に密接な関係にあつて生理的機能を営んでいるので両 者濃度間に一定の比率が存在する事が予想され，健常人及び糖尿病患者に就いて Insulin like activity 及び Glucagon like activity の同時測定を行い,多数の平均としてほほ Insulin $1(\mathrm{U} / \mathrm{ml})$, Glucagon $10(\mu \mathrm{g} / \mathrm{ml})$ の比が成立するが如き印象を得る事ができた。

一方 Glucagon と肝糖原との対応は当然想定される所で，上膵十二指腸静脈と頸静脈等の末梢血について Glucagon-like activity を測定し，肝㘕通過によるGlucagon activity の減少から Glucagon と肝糖原との 相互作用を窅い，肝糖原高值の場合にはその分解の為消費される Glucagon activity も多量となり末梢 Glucagone activity は低下し，その較差が著明になる事を証明出来るであろうとの想定を持つていたにも関らず， Glucagon activity 較差は必ずしも肝糖原量に比例せず，乙の面からも Glucagon effect は単に血中 Glucagon 量と肝糖原のみで決定されるのではなく, 恐らく Insulin との共存によつてその Activity が修飾を 受けているものと考えられ，極端には生体内でも in vitroに於ける Insulin free の BG medium に Glucagon を添加した場合と同様に, Insulin activity゙が低值をとる等の場合には Glucagon が肝糖原に殆んど 影響を与えないのではないかとも考えられる。

Insulin sensitivity が血中 Glucagon like activity と逆相関をなす事に対する考光は，上述の思考を推 進したものであつて稍々技巧的な仮説ではあるが，in vitro の Insulin 及び Glucagon の相互作用よりみ ればもつとも理解しやすい仮説である.

III 考按

Glucagon の肝 Phosphorylase 再活性化促進による肝糖原分解作用に就いては Sutherland $ら^{22 \sim 4)}$ の業績 が明確な機作を示しているにも関らず，その生理的或は病態生理的作用に就いては不明の点が多く，一見疑 問の余地のない肝糖原分解機作に就いても具体的に白鼠肝切片を in vitro で incubate し, Glycogen 減 少, 糖放出増加等として取扱つてみると肝切片側の状態を含め各種条件によつて複雑な変動を示し, 殊に Insulin 等の他のホルモンとの干渉の結果, 酵素系への Glucagon 作用が直接測定に反映しているものとし ては一律に解橎し得ない場合が多い.

生体内に於て Glucagon の微量定量法が完成していない事がその生理作用解明を阻んでいた事は明らか で教室松岡 ${ }^{29}$ ，魚川 ${ }^{300}$ 亿依つて一部ての方面の研究が行われているが，著者は先ず肝との相互作用を解明す る事が重要であると考え，酵素系の変化を生体に結びつける過程として in vitro に於て白鼠肝切片を用い て Glucagon の各種濃度に於ける糖利用及び糖原変動を測定し，殊に生体内では必ず共存する Insulinの 各種濃度を同時に添加しその相互関係をあきらかにせんと試みた。

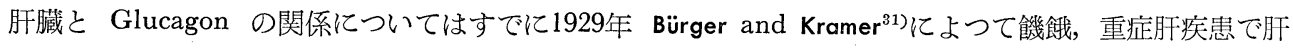
糖原減少著明な時には Glucagon effect としての過血糖が認められない場合のある事が報告され，以来肝臟 摘出動物では血糖反応なく ${ }^{32) ~}{ }^{34)}$, 絶食時間に依り反応度が減弱し ${ }^{35) 36)}$, 肝臟機能不全のものは反応が異る ${ }^{37}$ 等 Glucagon effect が肝臓殊に肝糖原量と直接関係ありとする ${ }^{38)}$ 事実が集積されている，又 Kibler and Meyer $^{39}$ 及び゙ Clancy $ら^{40)}$ の肝カテーテルに依る実験は Glucagon 注射によつて肝よりの糖放出を証明し， 又 Shoemaker $~^{41)}$ は肝糖放出と同時に肝血流量増加のある事を証明し，又一方 Goldner ら ${ }^{42}$ は肝灌流実験 で添加 Glucagon は 1 回の肝通過でその activity を消失する事を証明し，又最近の Glucagon $I^{121}$ を使用 
したCox ら ${ }^{43)}$ ，Berson $ら^{44)}$ 及び Narahara and Williams $\left.{ }^{45}\right)$ の実験結果も Glucagon の代謝が肝で行われ分 解が比較的速か飞行われる事を認めている。 その他に Haugaard $ら^{46) 47)}$, Davoren and Bornstein ${ }^{48}$ が指摘す る様に肝の脂質代謝に於ける役割を無視する事は出来ないが，上記の如く肝糖原に作用して糖放出を起さし め自体は速汃分解をうけるものと理解される。併し乍らての様な Glucagon の肝に対する作用が単に肝 糖原量のみによつて一方的に決定されると考えるのはあまりに単純であつて, 著者の成績でも正常犬肝糖原 量と膵十二指腸静脈血中 Glucagon activity 対末梢血中 Glucagon activity 較差との間に一定の関係を兄 出していない，従つて生体内に共存する Insulin 等の影響がぞの程度, ぞの様にしてての Glucagon 作用 亿影響しているかを知る事が重要であり, 又興味ある課題と云える.

この意味で先ず Insulin 作用と Glucagon に就いての従来の業績を眺めてみると, Bürger and Brandt ${ }^{1)}$ は食餌性の高血糖極期には Insulin 分泌に先立つて Glucagon 分泌相のある事を見出し, Glucagon は Insulin と協調作用を持つ事を主張し，Rootら ${ }^{49}$ はInsulin と混合注射してもその低血糖作用を障碍しない事 を認め，更に Erlick $ら^{50)}$ は臨床的にも Glucagon の適量投与に依つて A-V ratio の上昇即ち未梢糖利用促 進の像を得る事に依り Insulin 作用に対する Glucagon の協調作用を認めている。研し乍ら肝臓沉於け る Insulin と Glucagon との関係に就いては, 前述の如く Tyberghein ${ }^{25)}$ そつて肝切片の Glucagon に よる Glycogenolysis に際して Insulin が Corticotropin, Casein 等と共に増強作用を示す事が報告されて いるが, Cystine 不活性化 Insulin によつてもほぼ同栐の結果が得られているので特異性があるものとは云 えない様に思う。

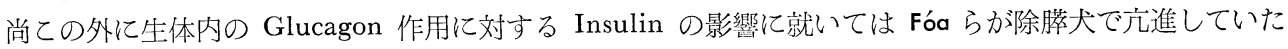
Glucagon effect が Insulin によつて低下するのを見出しているに過ざない. 著者の in vitro の成績によ つてみても Insulin は Glucagon の肝切片糖原分解を促進する事に問違いなく，しかも Insulin と Glucagon との濃度比に依る作用の相違, 例えばBG $\left(10^{-4}\right)$ に於ける Insulin 添加増量は Insulin effect として の Glucose uptake の増大を伴い得るが，BG(1.0) では逆に Glucagon effect を増大し Glucose uptake, AGlycogen を減少せしめる等の事実，及び解糖抑制の時間的観察より Glucagon 分解が Insulin によつ て防止されるだけでなく両者の量的関係が相互にその作用に影響を与えている事を推測せしめた。

上記の考えで計画した in vivoの実験によつて著者の得た結果は，正常犬門脈内に Glucagon + Insulin 混合液を注入する事により Glucagon 高血糖の増大とInsulin 反応性低血糖増強とを明か䎲証明する事が 出来た. 即ち Insulin $1(\mathrm{unit} / \mathrm{ml})$ : Glucagon $10(\mu \mathrm{g} / \mathrm{ml})$ の比がGlucagon の肝糖原分解に対してもつとも有 效であると考えられると同時に, 肝通過後末梢血中ではInsulin は肝通過で殆んど分解されない (Narahara $\left.{ }^{45}\right)$ が, Glucagon は殆んぞ肝臟に於て分解され(平常安静状態で約 3 分の 1 亿低下)ているのでての比は Insulin effect 亿対し最適のものに変化するのではないかとも思われる.

Elrick $ら^{46)} の$ Insulin 作用に対する Glucagon の影響に就いての成績からみると, Insulin 4.6r (Ca12U) /min., Glucagon 1.2 r/min. の混合がもつとも A-V ratio の增大を俳う未梢糖利用を促進するとしているが， 之は主として末梢糖利用を指標としたものであつて，著者の実験とは自ら異る.

又上記の考えから糖尿病患者及び正常人血中 Glucagon like activity, Insulin like activity の比をみて みると約10:1となつて居り，ての比の変化から Insulin sensitivity と Glucagon like activity の逆相関 関係も説明出来ると思われる。

\section{結語}

Warburg 装置を使用した in vitro の実験伦て，著者は Glucagon 及び Insulin の漕度を種々変更し て組み合わせ，白鼠肝切片糖利用及び糖原変動に対する影響を钼察し，更に正常大門脈内に Insulin 及び Glucagnn を注入し, 肝糖原量, 血糖を測定し，膵十二指腸静脈血中及び末梢静脈血中の Glucagon like activity と肝糖原量の関係を観察し, 又正常人及び糖尿病者の血清 Glucagon like activity 及び Insulin like activity を同時に測定しその相互作用を検討し，更に Insulin sensitivity と血清 Glucagon like 
activity との関係をみて次の結果を得た。

1) BG medium に添加された Insulin の増量につれ肝切片の Glucose uptake, JGlycogen は共に増 加する。

2) BG medium に添加された Glucagon の低濃度の場合は肝切片の代謝に殆んぞ影響なく，1 $1 \mu \mathrm{g} / \mathrm{ml}$ 以上に於て僅かに Glucose uptake 低下と 4 Glycogen 減少をみるのみである.

3） $10^{-4} \mu \mathrm{g} / \mathrm{ml}$ Glucagon を含む BG medium 飞 Insulin を添加すると，增量につれて Glucose uptake は増加するが Glucagon 無添加の場合より増加率は低い. $\Delta$ Glycogen は添加 Insulin の増加につれて 減少する. BG $\left(10^{-2}\right)$ では Insulin 増加による Glucose uptake 增加と Glucagon potentiation による Glycogenolysis の影響が平衡し Glucose uptake は小変動にとどまる。

4) $1 \mu \mathrm{g} / \mathrm{ml}, \quad 10 \mu \mathrm{g} / \mathrm{ml}$ の Glucagon を含む BG medium そ Insulin を添加すると Insulin 増量につれ 益々 Glycogenolytic action が強くあらわれる。

5）之等 in vitro の変化の時間的な変動を追求し Adrenalin 添加の場合と比較し，Insulin が存在しな ければ Glucagon は約30分で影響を失い，120分後ではBG medium より糖利用が大となる，Insulinの 存在に依り Glucagon の作用が短時間内ではむしろ抑制される反面持続性を持つ事を見出した.

6) 正常犬門脈内に Insulin 及び Glucagon を同時投与した時の反応は各々の効果が増強され，Glucagon 単独よりも血糖上昇が高く, 反応性低血糖は Insulin 単独の場合より著明であつた。

7) 膵十二指腸静脈内 Glucagon like activity と末梢静脈血中 Glucagon like activity との較差は Glucagon と肝糖原との作用が直線的であれば比例的関係が見出されるとの想定のもとに実験を行つたが， その様な可能性を見出す事が出来なかつた。

8) 正常人及び糖尿病者の Insulin like activity 及び Glucagon like activity 同時測定の成績からほぼ Insulin $(\mathrm{U} / \mathrm{ml})$ : Glucagon $(\mu \mathrm{g} / \mathrm{ml})=1 ： 10$ をなす事，in vitro の添加実験でもこの比が有効である事から 血清中 Insulin, Glucagon ratio の意味を考察し, Insulin sensitivity との関係の説明を試みた。

稿を終るにあたり，終始御指導並びに御校閲を賜わつた恩師辻教授に深甚なる謝意を捧げます。

\section{文献}

1) Bürger, M. and Brandt, W. : Z. exp. Med., $96: 375$ (1935). $\quad$ 2) Sutherland, E.W. and Cori, C.F. : J. Biol. Chem., $172: 737$ (1948). $\quad$ 3) Sutherlond, E.W. and de Duve, C. : J. Biol. Chem., 175 : 663 (1948). 4) Sutherland, E.W. : Recent progr. Hormone Res., $5: 441$ (1950). 5) Bromer, W.W., Sinn, L.G., Staub, A. and Behrens, O. K. : Diabetes, $6: 234$ (1957). 6) Bürger, M. : Fortschr. d. Diagnostik u. Therapie., $1: 225$ (1950). 7) Pincus, J.J. and Rutman, J.Z.: A.M.A. Arch. intern. Med.,92 : 666 (1953). $\quad$ 8) Fóa, P.P.: Advanc. intern. Med., $6: 29$ (1954). 9) Volk, B.W., Lazarus, S.S. and Goldner, M.G. : A.M.A. Arch. intern. Med., $93: 87$ (1954). 10) 吉岡 : 内 分泌, $3: 97$ (1956). 11) 阿部, 小坂, 吉村: 膵藏之内分泌, 東京協同医書出版.

馬場：日内分泌誌，34:31 (1958)。 13) 新光：日内分泌誌，揭載予定 (1961). 14) Hagedorn， H.C. and Jensen, B.N. : Biochem. Z., $135: 46$ (1923). 15) Good, C.A., Kramer, H. and Somogyi, H. : J. Biol. Chem., $100: 485$ (1933). 16) Candela, J.L.R. : Ciba Found. Colloq. on Endocrinol., 6 : 233 (1953). 17) Candela, J.L.R. and Candela, R.R. : ibid., $9: 194$ (1956). 18) Snedecor, J.G., De Meio, R.H. and Pincus, J.J. : Proc. Soc. exp. biol. et məd. N.Y., $89: 396$ (1955). 19) 阿 部, 井川, 森田, 猪熊, Deur, 石母田, 南, 神倉, 鈴木, 中原, 佐々木, 西山, 中西, 鳥海, 小島, 永島, 田島: 内分泌, $3: 299$ (1956). 20 ) 阿部, 森田, 中原, 柏川 : 日本生理誌, $19: 755$ (1957). 21) Smith, R.H. : Cited by Young, F. G. in Ciba Found. Colloq. on Endocrinol., 6:241 (1953).

22) Randle, P.J. : J. Endocrinol., $14: 82$ (1956).

(1958). 24) 島津：日消誌，57:827 (1960).
23) Randle, P.J. : J. Endocrinol., $17: 396 \sim 400$ 25) Tyberghein, J.M., Tomizawa, H.H. and

$$
\text { 第37巻 第 } 8 \text { 号 }
$$


Williams, R.H., : J. biol. Chem., 222 : 945 (1956). 26) de Duve : Ciba Found. Colloq. on Endocrinol., 9 : 32 (1956). 27$)$ 辻, 新光, 島津 : 綜合臨床, $8: 96$ (1959), 28$)$ 馬場, 新光, 森下 : 最 新医学, $15: 317(1960)$. 29) 松岡：日内分泌誌, 掲載予定 (1961). 30$)$ 魚川 : 日内分泌誌, 掲載予定 (1961)。 31) Bürger, M. and Kramer, H. : Ztschr. ges. exp. Med., 65 : 489 (1929), $67: 441$ (1929). 32) Ingle, D.J. Nezamis, J.E. and Humphrey, L.M. : Proc. Soc. exp. Biol. \& Med., 84 : 232 (1953). 33) Pincus, I.J. and Rutman J.Z. : Arch. int. Med., $92: 666$ (1953). 34) Weisberg, H.F. Caren, R., Huddlestum, B. and Levine, R. : Amer. J. Physiol., $159: 98$ (1949). $\quad 35)$ Pincus, I.J. : J. Clin. Endocrinol., $10: 556$ (1950). 36$)$ 阿部，中野：ホルモンと臨床，2:150. 37) Van Itallie, T.B. and Bantley W.B.: J. Clin. Invest., $34: 1730$ (1955). $\quad 38)$ Helmer, D.M. and Root, M.A. : Endocrinol., $54: 338$ (1954). $\quad 39)$ Kibler, R.E. and Meyer, J.D. : Amer. J. Med., $14: 753$ (1953). $\quad 40)$ Clancy, R.E., Van Itallie, T.B., Spodick, D.H., Wilder, C.E. and Litmann, D. : Fed. Proc., $16: 382$ (1957). $\quad$ 41) Shoemaker W.C., Van, Itallie, T.B. and Walker, W.F. : Am. J. of Physiol., 196 : 315 318 (1959). $\quad$ 42) Goldner, M.G., Jauregui, R.H. and Weisenfeld, S. : Am. J. of Physiol., 179 : 25 (1954). 43) Cox, R.W., Henley, E.D., Narahara, H.T., Vanarsdel, P.R. and Williams, R.H. : Endocrinol., 60 : 277 (1957). $\quad 44)$ Berson, S.A., Yalow, R.S., Volk, B.W. and Bronx, N.Y. : J. Lab. Clin. Med., $49: 331$ (1957). $\quad$ 45) Narahara, H.T. and Williams, R.H. : Endocrinol., 60 : 285 (1957). 46) Haugaard, E.S. and S tadie, W.C. : J. Biol. Chem., $200: 753$ (1953). 47 ) Haugaard, E.S. and Haugaard, N. : J. Biol. Chem., $206: 641$ (1954). 48) Davoren, R.R. and Bornstein, J.: Am. J. Physiol., $197: 887$ (1959). $\quad$ 49) Root, M.A., Ellis, J. and Staub, A. : Proc. Soc. exp. Biol. Med. 85 : 507 (1954). $\quad$ 50) Elrick, H., Witten, T. and Arai, Y. : New England J. Med., $258: 476$ (1958). 